\title{
DAMPAK PANDEMI COVID-19 TERHADAP PROSES PEMENUHAN KEWAJIBAN PERPAJAKAN OLEH WAJIB PAJAK YANG TERDAFTAR PADA KANTOR PELAYANAN PAJAK (KPP) PRATAMA PONTIANAK TAHUN 2020
}

\author{
Sari Zawitri ${ }^{\text {1), Ninik Kurniasih }}{ }^{2)}$, \& Wida Arindya Sari ${ }^{\text {3) }}$ \\ 1,2,3 Jurusan Akuntansi Politeknik Negeri Pontianak \\ ${ }^{1}$ email: zawiakpolnep@gmail.com
}

\begin{abstract}
The purpose of this research is to see the impact on tax revenue, and the impact on out in tax reporting KPP Pratama in Pontianak in the pandemic covid 19. The research is a case study of exploration and researches the mixing of qualitative and quantitative methods. The kind of data that was used was the data as primary and secondary data. The technique of the data collection was done in 3 ways: 1. Interview, 2. Documentation, and 3. A method of the literature study. Then sample based on the achievement of the depth and wealth a description of, not the total sample. Analysis technique that produces the thematic analysis answer the interviews and of identification and reporting the data from the payment of tax like both of persons private and the tax year 2019. The result showed (1) research first showed that Covid-19 fulfillment of obligations would not have an impact on both the taxpayers and the person in the pay taxes on income tax PPh and PPN (tax) they increase in value. (2) the results of research second related fulfillment of an obligation related tax reporting SPT (announcement letter) an annual tax for the year 2019 declining tax effectively be $76 \%$ or at the level of less docile, it is related to the development of the target the reporter threefold. The research is expected to push the government to optimize sources of certain tax revenue to offset the impact of tax revenue when pandemic Covid-19.
\end{abstract}

Keywords: Covid-19, Corporate Taxpayers, Income Tax, Personal Taxpayers, SPT the Income Tax.

\section{PENDAHULUAN}

Pendemi Covid (Corona Virus Disease) 19 menyerang Indonesia pada awal tahun 2020 dan berdampak terhadap perekonomian, antara lain : turunnya Indeks Harga Saham Gabungan (IHSG), melemahnya nilai tukar rupiah, dan terjadi kenaikan harga barang di pasaran. Peran Pemerintah, yaitu Menteri Keuangan bersama Direktorat Jenderal Pajak (DJP) dengan fungsi regulerend dan budgeter membantu menstabilkan kondisi ekonomi dengan kebijakan fiskal dan moneter.
Kebijakannya sebagai berikut: Peraturan Pemerintah RI Nomor 1 Tahun 2020 tentang Kebijakan Keuangan Negara dan Stabilitas Sistem Keuangan untuk Penanganan Covid-19 dan/atau Dalam Rangka Menghadapi Ancaman Yang Membahayakan Perekonomian Nasional dan/atau Stabilitas Sistem Keuangan. Dan Peraturan Menteri Keuangan RI Nomor 23/PMK.03/2020 tentang Insentif Pajak untuk Wajib Pajak Terdampak Wabah Virus Corona serta Peraturan DJP Nomor Per-06/PJ/2020 tentang Tatacara Penyampaian, Penerimaan dan Pengolahan Surat Pemberitahuan Pajak 
Penghasilan Tahun Pajak 2019 Sehubungan dengan Pendemi Covid-19.

Perpu No. 1 terdapat 3 kebijakan: penurunan tarif $\mathrm{PPh}$ badan dari $25 \%$ menjadi $22 \%$ dan $20 \%$ serta pengurangan tarif 3 poin persentase lebih rendah bagi wajib pajak badan yang go public, pemajakan atas transaksi elektronik, perpanjangan jangka waktu permohonan atau penyelesaian administrasi perpajakan. Kemudian terkait PMK No.23 terdapat 4 insentif pajak: PPh Pasal 21 ditanggung pemerintah, pembebasan $\mathrm{PPh}$ Pasal 22 Impor, pengurangan $\mathrm{PPh}$ Pasal 25 sebesar 30\%, restitusi PPN dipercepat untuk eksportir dan noneksportir.

Akhir bulan Maret dan April 2020 batas akhir pemenuhan kewajiban Perpajakan untuk tahun Pajak 2019, sedangkan waktu tersebut merupakan puncak pendemi Covid-19 di Indonesia. Awal April Kementerian Keuangan melakukan konfrensi pers mengenai dampak Covid-19 dimana banyak masyarakat yang bekerja pada sektor informal kehilangan pendapatan, kredit macet pada UMKM, karena tidak bisa menjalankan usaha secara normal. Hal terkait hilangnya pendapatan masyarakat dan menurunnya pendapatan UMKM tentu akan berpengaruh pada pemenuhan kewajiban perpajakan mereka. Dengan mempertimbangkan beberapa hal terkait kebijakan yang dipaparkan sebelumnya, kinerja pajak yang optimal tetap dibutuhkan di tengah adanya kebutuhan berbagai relaksasi. Maka peneliti tertarik merumuskan 2 (dua) permasalahan berikut:

1. Bagaimana dampak penerimaan pajak baik dari segi kuantitas maupun kualitas saat pendemi Covid-19?

2. Bagaimana dampak pelaporan pajak baik dari kelengkapan administrasi maupun ketepatan waktu wajib pajak orang pribadi dan badan saat pendemi Covid-19?

\section{KAJIAN LITERATUR}

\subsection{Pandemi Covid-19}

Wikipedia menterjemahkan pandemi Covid-19 adalah peristiwa menyebarnya penyakit koronavirus 2019 (coronavirus disease 2019, disingkat Covid-19) di seluruh dunia. Penyakit ini disebabkan oleh koronavirus jenis baru yang diberi nama SARS-CoV-2.

\subsection{Fungsi Pajak}

Menurut Resmi (2011) terdapat dua fungsi pajak yaitu antara lain.

1. Fungsi Sumber Keuangan Negara (Budgetair) Adalah pajak berfungsi salah satu sumber penerimaan pemerintah untuk membiayai pengeluaran baik rutin maupun pembangunan

2. Fungsi Pengatur (Regulerend) Adalah sebagai alat untuk mengatur atau melaksanakan kebijakan pemeintah dalam bidang sosial dan ekonomi, serta mencapai tujuan-tujuan tertentu di luar bidang keuangan.

\subsection{Macam-Macam Hak dan Kewajiban Perpajakan}

Berdasarkan definisi tentang Wajib Pajak, kewajiban perpajakan yang akan timbul menurut Mardiasmo (2013) adalah sebagai berikut.

1. Mendaftarkan diri untuk mendapatkan Nomor Pokok Wajib Pajak (NPWP)

2. Melaporkan usahanya untuk dikukuhkan sebagai Pengusaha Kena Pajak (PKP)

3. Menghitung dan membayar sendiri pajak dengan benar

4. Mengisi SPT (diambil sendiri mengambil dengan cara lain yang tata cara pelaksanaannya diatur dengan atau berdasarkan Peraturan Menteri Keuangan) dengan benar, lengkap, dan jelas, dalam bahasa Indonesia dengan menggunakan huruf Latin, angka Arab, satuan mata uang Rupiah, dan menandatangani serta yang Terdaftar pada Kantor Pelayanan Pajak (KPP) Pratama Pontianak Tahun 2020 
menyampaikannya ke KPP tempat terdaftar.

5. Menyelenggarakan pembukuan/pencatatan

6. Jika diperiksa wajib:

a. Memperlihatkan dan atau meminjamkan buku atau catatan, dokumen yang menjadi dasarnya dan dokumen lain yang berhubungan dengan penghasilan yang diperoleh, kegiatan usaha, pekerjaan bebas Wajib Pajak, atau objek yang terutang pajak.

b. Memberikan kesempatan untuk memasuki tempat atau ruangan yang dipandang perlu dan memberi bantun guna kelancaran pemeriksaan.

7. Apabila dalam waktu mengungkapkan pembukuan, pencatatan atau dokumen serta keterangan yang diminta, Wajib Pajak terikat oleh suatu kewajiban untuk merahasiakan, maka kewajiban untuk merahasiakan itu ditiadakan oleh permintaan untuk keperluan pemeriksaan.

Kemudian Mardiasmo (2013) juga merumuskan hak-hak yang diperoleh sebagai Wajib Pajak antara lain:

1) Mengajukan surat keberatan dan banding

2) Menerima tanda bukti pemasukan SPT

3) Melakukan pembetulan SPT yang telah dimasukkan

4) Mengajukan permohonan penundaan penyampaian SPT

5) Mengajukan permohonan penundaan atau pengangsuran pembayaran pajak

6) Mengajukan permohonan perhitungan pajak yang dikenakan dalam surat ketetapan pajak

7) Meminta pengmbalian kelebihan pembayaran pajak

8) Mengajukan permohonan penghapusan dan pengurangan sanksi, serta pembetulan surat ketetapan pajak yang salah
9) Memberi kuasa kepada seseorang untuk melaksanakan kewajiban perpajakannya

10) Meminta bukti pemotongan atau pemungutan pajak

11) Mengajukan keberatan dan banding

\subsection{Kepatuhan Wajib Pajak}

Kepatuhan memenuhi kewajiban perpajakan secara sukarela (voluntary of complience) merupakan tulang punggung dari self assesment system, dimana wajib pajak bertanggung jawab menetapkan sendiri kewajiban perpajakan kemudian secara akurat dan tepat waktu dalam membayar dan melaporkan pajaknya. Pengertian kepatuhan Wajib Pajak menurut Safri Nurmantu yang dikutip oleh Rahayu (2010), menyatakan bahwa:

"Kepatuhan perpajakan dapat didefinisikan sebagai suatu keadaan dimana Wajib Pajak memenuhi semua kewajiban perpajakan dan melaksanakan hak perpajakannya".

Pengertian kepatuhan Wajib Pajak menurut Chaizi Nasucha yang dikutip oleh Rahayu (2010), menyatakan bahwa kepatuhan Wajib Pajak dapat didefinisikan dari:

1) Kewajiban Wajib Pajak dalam mendaftarkan diri.

2) Kepatuhan untuk menyetorkan kembali Surat pemberitahuan.

3) Kepatuhan dalam perhitungan dan pembayaran pajak terutang.

4) Kepatuhan dalam pembayaran tunggakan. 


\subsection{Bagan Penelitian}

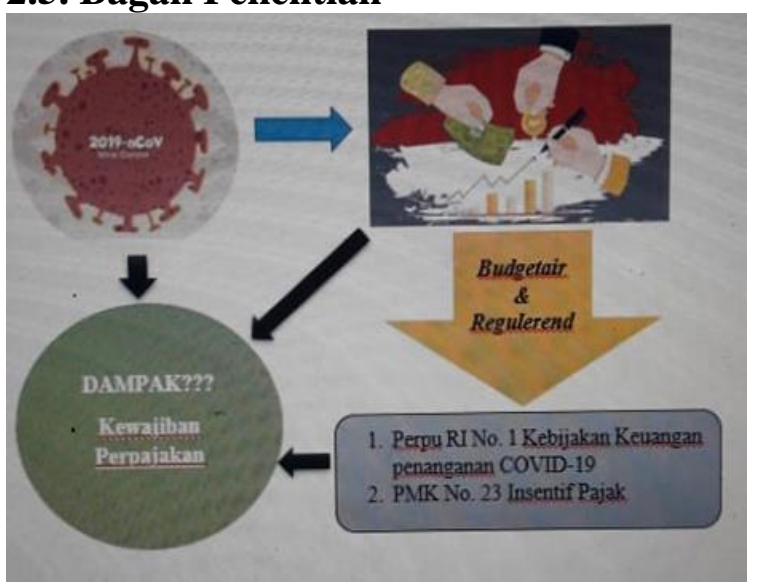

Gambar 2.1 Bagan Penelitian

Gambar 2.1 Bagan Penelitian yang dirancang sesuai latar belakang dan identifikasi masalah pada Bab 1 . Kerangka pemikiran berawal dari Pendemi Covid-19 yang berdampak pada stabilitas perekonomian Indonesia. Kemudian Pemerintah mengeluarkan kebijakan-kebijakan mempengaruhi pemenuhan kewajiban perpajakan masyarakat.

\section{METODE PENELITIAN}

\subsection{Tempat dan Waktu Penelitian Tempat Penelitian}

Memperhatikan konsep penelitian, maka yang menjadi tempat penelitian adalah KPP Pratama Pontianak. KPP Pratama Pontianak memiliki jumlah Wajib Pajak Orang Pribadi dan Badan terbesar, jika dibandingkan dengan KPP Pratama Kabupaten lainnya di Kalimantan Barat. Penelitian ini melihat dampak pendemi Covid-19 terhadap proses pemenuhan kewajiban perpajakan wajib pajak orang pribadi dan badan yang terdaftar di KPP Pratama Pontianak.

\section{Waktu Penelitian}

Waktu Penelitian ini memerlukan waktu sekitar 8 bulan (April 2020 sampai November 2020) dengan menggunakan metode studi kasus eksplorasi dan pendekatan penelitiannya menggunakan metode 2 (dua) kualitatif dan kuantitatif yang digunakan untuk mendapatkan informasi kendala dan akibat dari pandemik COVID-19 terhadap kegiatan proses pemenuhan kewajiban perpajakan.

\subsection{Jenis dan Bentuk Penelitian Jenis Penelitian}

Penelitian ini adalah penelitian dengan jenis riset eksploratoria yang bersifat deskriptif naratif. Penelitian eksploratoria adalah suatu penelitian yang dilakukan untuk memperoleh keterangan, penjelasan, dan data mengenai hal- hal yang belum diketahui. Dalam penelitian ini menggunakan sampel 7 responden mewakili Pegawai KPP dan perwakilan Wajib Pajak yang terlibat langsung sebagai petugas pelayanan pajak dan wajib pajak yang sedang melakukan pemenuhuan kewajiban perpajakannya untuk diwawancara yang diambil dengan accidental sampling. Ukuran sampel didasarkan pada pencapaian kedalaman dan kekayaan deskripsi, bukan jumlah sampel. Menurut Guetterman (2015), ukuran sampel bukan masalah opini representatif dan pandangan, tetapi lebih merupakan masalah kekayaan informasi.

\section{Bentuk Penelitian}

Penelitian merupakan penelitian deskriptif kuantitatif. Penelitian ini termasuk dalam penelitian deskriptif yaitu penelitian yang dimulai dari pengumpulan data, menginventarisasikan, mengolah data hingga menyajikan hasil-hasil yang disertai dengan interpretasi sehingga diperoleh gambaran yang jelas tentang pokok permasalahan yang diteliti.

\subsection{Parameter Pengamatan}

Parameter pengamatan menguraikan teknik pengumpulan data atau bagaimana data dapat diikhtisarkan dan dikumpulkan, sumber data dengan cara yang Terdaftar pada Kantor Pelayanan Pajak (KPP) Pratama Pontianak Tahun 2020 


\section{Teknik Pengumpulan Data}

Metode pengumpulan data dalam penelitian ini dilakukan dengan

1) Wawancara, dilakukan dengan memberikan pertanyaan terkait dampak pendemi COVID-19 terhadap pelayanan yang diberikan dalam proses pemenuhan kewajiban perpajakan terutama pada batas waktu pelaporan yaitu 30 Maret untuk wajib pajak orang pribadi dan 31 April untuk wajib pajak badan. Dan wawancara terhadap wajib pajak yang ditemui dan sedang melaporkan atau konsultasi terhadap kewajiban perpajakannya. Semua wawancara, dengan izin dan persetujuan yang ditandatangani, direkam secara audio dan kemudian di transkrip secara verbal.

2) Dokumentasi, yaitu mengumpulkan data dengan cara mencatat dokumen yang berhubungan dengan penelitian ini. Data dokumentasi merupakan data penerimaan pembayaran pajak dan pelaporan SPT baik orang pribadi maupun badan untuk tahun pajak 2019,

3) Metode studi pustaka, yaitu dengan melakukan telaah pustaka, eksplorasi dan mengkaji berbagai literature pustaka seperti buku-buku, jurnal, masalah, literatur, dan sumber-sumber lain yang berkaitan dengan penelitian.

\section{Sumber Data}

Dalam penelitian ini penulis menggunakan data primer hasil wawancara semi-terstruktur kepada petugas pelayanan maupun yang bertanggungjawab dalam proses pelaporan perpajakan baik kewajiban SPT Masa maupun SPT Tahunan, beserta wajib pajak yang sedang melakukan pelaporan pajak maupun konsultasi pajak pada KPP Pratama Pontianak. Dan data sekunder adalah dokumentasi data penerimaan pembayaran pajak dan pelaporan SPT baik orang pribadi maupun badan untuk tahun pajak 2019. Dengan dilengkapi data jumlah wajib pajak serta dokumen pendukung lainnya.

\subsection{Teknik Analisis Data}

Teknik analisa data dilakukan dengan pendekatan tematik yang menghasilkan analisis mendalam dari jawaban hasil wawancara. Analisis dan interpretasi data adalah bagian paling kritis dan dianggap paling tepat untuk setiap penelitian yang berupaya mengeksplorasi apa yang sesungguhnya terjadi dalam sebuah fenomena. Tahapan melakukan tematik analisis yaitu: (1) Memahami data, (2) Menyusun kode semua data dalam transkrip, (3) Mencari tema sesuai dengan tujuan penelitian, (4) Simpulan. Analisa juga dilakukan dari tela'ah data penerimaan pembayaran pajak dan pelaporan SPT baik orang pribadi maupun badan untuk tahun pajak 2019. Setelah analisis tematik, peneliti akan menggambarkan temuan, sesuai dengan rumusan masalah.

Terkait data sekunder dengan membandingkan target dan realisasi penerimaan dan pelaporan pajak baik orang pribadi maupun badan yang terdaftar di Kantor Pelayanan Pajak Pratama Pontianak. Dan kemudian membandingkan angka di tiga tahun terakhir pemenuhan kewajiban pajak tersebut. Analisis dilakukan dengan 2 (dua) tahapan:

1) Tahapan pertama merupakan analisis yang dapat digunakan untuk mengetahui bagaimana pemenuhan kewajiban pajak oleh Wajib Pajak berdasarkan ketetapan pajak apakah Patuh atau Kurang Patuh dengan menggunakan rumus sebagai berikut:

Kepatuhan WP $(P K P)=\frac{R}{T c} \times 1 \%$

Keterangan:

$\mathrm{R}=$ Realisasi Penerimaan/Pelaporan Pajak pada tahun pajak tertentu 
Tc $=$ Target Penerimaan/Pelaporan Pajak pada tahun pajak tertentu

Sumber: Susan, dkk (2015)

2) Tahapan kedua merupakan analisa berikutnya, yang dilakukan membandingkan hasil penilaian kepatuhan pada tahun pajak sebelumnya $(2017,2018)$ dan tahun pajak terdampak COVID 19.

Hasil perhitungan dalam bentuk prosentase, kemudian dilakukan penyesuaian dengan Tabel Kriteria Kepatuhan Wajib Pajak berikut ini:

Tabel 3.1 Kriteria Kepatuhan Wajib Pajak

\begin{tabular}{|c|c|}
\hline $\begin{array}{c}\text { Kepatuhan Wajib } \\
\text { Pajak }\end{array}$ & Rasio \\
\hline Sangat Patuh & $>100$ \\
\hline Patuh & $90-100$ \\
\hline Cukup Patuh & $80-90$ \\
\hline Kurang Patuh & $60-80$ \\
\hline Tidak Patuh & $\leq 60$ \\
\hline
\end{tabular}

Sumber: Susan, dkk (2015)

\section{HASIL}

\section{Hasil Penelitian}

Untuk melihat dampak COVID 19 terhadap pemenuhan kewajiban perpajakan dilakukan analisa dengan data 3 (tiga) tahun terakhir mengenai Target dan Realisasi Penerimaan Pajak Penghasilan Tahun 2017, 2018 dan 2019. Dimana kewajiban perpajakan pada tahun pajak 2019 harus terpenuhi pada awal tahun 2020, tepatnya pada bulan Maret untuk Wajib Pajak Orang Pribadi dan April unuk Wajib Pajak Badan saat Pendemi Covid (Corona Virus Disease) 19 menyerang Indonesia. Data tersebut ditampilkan dalam data sebagai berikut:
Tabel 4.1 Target dan Realisasi Penerimaan PPh Tahun 2017-2019 (dalam ribuan rupiah)

\begin{tabular}{|l|l|l|l|l|}
\hline No & Tahun & Target & Realisasi & $\begin{array}{l}\text { \% } \\
\text { Capaian }\end{array}$ \\
\hline 1 & 2017 & 3.672 .819 .954 & 2.732 .986 .288 & $74 \%$ \\
\hline 2 & 2018 & 3.891 .012 .511 & 3.108 .743 .984 & $80 \%$ \\
\hline 3 & 2019 & 3.798 .620 .139 & 3.342 .326 .537 & $88 \%$ \\
\hline
\end{tabular}

Sumber: Data Olahan

Pada tabel 4.1 dapat dilihat terjadi peningkatan realisasi penerimaan $\mathrm{PPh}$ (Pajak Penghasilan) dari tahun ke tahun, bahkan prosentase capaian juga meningkat, tahun 2017 74\%, tahun 2018 80\% dan tahun 2019 meningkat menjadi $88 \%$. Dari informasi data yang didapat dapat dilihat pada tahun pajak 2019, dimana penyelesaian pembayarannya pada awal tahun 2020 terjadinya wabah COVID 19 Wajib Pajak masih mampu untuk memenuhi kewajiban pembayaran pajak penghasilannya. Namun sedikit perbedaan terkait realisasi penerimaan PPN ditampilakan dalam Tabel 4.2 berikut ini:

Tabel 4.2 Target dan Realisasi

Penerimaan PPN Tahun 2017-2019 (dalam ribuan rupiah)

\begin{tabular}{|l|l|l|l|l|}
\hline No & Tahun & Target & Realisasi & $\begin{array}{l}\text { Capaian } \\
\text { Capia }\end{array}$ \\
\hline 1 & 2017 & 2.799 .336 .168 & 2.836 .559 .774 .006 & $101 \%$ \\
\hline 2 & 2018 & 3.237 .017 .954 & 3.075 .539 .525 .628 & $95 \%$ \\
\hline 3 & 2019 & 3.760 .279 .644 & 3.125 .597 .930 .515 & $83 \%$ \\
\hline
\end{tabular}

Sumber: Data Olahan

Pada tabel 4.2 menunjukkan peningkatan jumlah realisasi penerimaan PPN (Pajak Pertambahan Nilai) dimana tahun $2017 \quad$ sebesar Rp 2.836.559.774.006,00 Tahun 2018 sebesar Rp 3.075.539.525.628,00 dan meningkat sebesar Rp 50.058.404.887,00 menjadi Rp 3.125.597.930.515,00. Namun untuk prosentase dengan membandingkan target dan realisasi menurun hingga $12 \%$ dari 95\% pada tahun 2018 menjadi 83\% ditahun pajak 2019. 
Dari analisa data secara kuantitatif dapat terlihat bawah jumlah penerimaan PPh maupun PPN mengalami peningkatan untuk tahun pajak 2019 walaupun penyelesaian kewajiban tersebut di awal tahun 2020, dimana perekonomian Indonesia sangat terdampak oleh COVID 19. Maka kemudian dapat dianalisa dari jumlah wajib pajaknya baik badan maupun orang pribadi yang mungkin saja mengalami peningkatan, dapat dilihat dalam tabel 4.3 .

Tabel 4.3 Wajib Pajak yang Terdaftar di Wilayah Pontianak Tahun 2017-

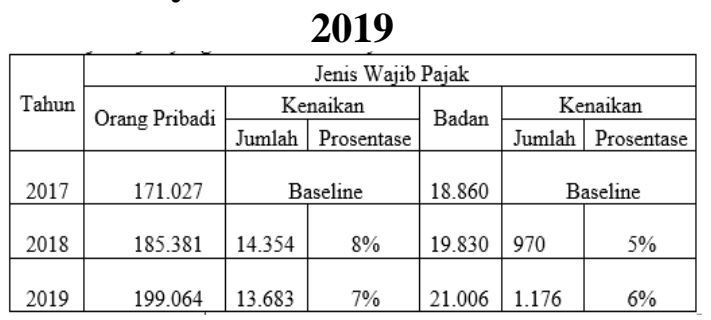

Sumber: Data Olahan

Pada Tabel 4.3 dapat terlihat jumlah wajib pajak selalu mengalami peningkatan dari tahun ketahun baik wajib pajak orang pribadi maupun wajib pajak badan. Untuk orang pribadi misalnya dari tahun pajak 2017 ke tahun pajak 2018 meningkat sebanyak 14.354 orang dan wajib pajak badan meningkat menjadi 970 usaha. Begitu pula untuk tahun pajak 2019 terjadi peningkatan wajib pajak orang pribadi menjadi 199.064 dan wajib pajak badan menjadi 21.006. Peningkatan untuk wajib pajak orang pribadi tahun 2019 adalah sebanyak 13.683 atau sebesar $7 \%$ dibandingkan tahun sebelumnya. Dan untuk wajib pajak badan meningkat sebanyak 1.176 atau sebesar $6 \%$ dibandingkan tahun 2018. Maka bisa saja peningkatan penerimaan pajak terjadi karena adanya penambahan wajib pajak yang terdaftar.

Kemudian dilakukan juga analisa terkait dengan pemenuhan kewajiban perpajakan terkait pelaporan SPT (Surat Pemberitahuan) Pajak Tahunan untuk tahun pajak 2019, yang dilakukan setelah selesai satu tahun pajak yang artinya dilaporkan pada tahun 2020. Dengan ketentuan paling lambat lapor akhir bulan Maret 2020 untuk Wajib Pajak Orang Pribadi dan akhir bulan April untuk Wajib pajak Badan. Namun untuk membandingkan tingkat kepatuhan Lapor SPT ditampilkan data 3 tahun terakhir (2017,2018 dan 2019). Adapun data pelaporan SPT dapat dilihat pada tabel 4.4 .

Tabel 4.4 Target dan Realisasi Lapor SPT Tahunan 2017-2019

\begin{tabular}{|c|c|c|c|c|}
\hline No $_{0}$ & Tahun & Target & Realisasi & \% Capaian \\
\hline 1 & 2017 & 16.826 & 18.877 & $112 \%$ \\
\hline 2 & 2018 & 19.473 & 22.666 & $116 \%$ \\
\hline 3 & 2019 & 86.785 & 66.380 & $76 \%$ \\
\hline
\end{tabular}

Sumber: Data Olahan

Tabel 4.4 menunjukkan adanya peningkatan target Wajib Pajak pada tahun pajak 2019 yang diharapkan melaporkan SPT Tahunan hingga sebesar 86.785, yaitu meningkat sebanyak 67.312 dari tahun sebelumnya 2018. Namun terlihat realisasi penerimaan Laporan SPT Tahunan pada tahun pajak 2019 hanya sebesar 66.380 atau $76 \%$. Hal ini memperlihatkan penurunan yang cukup signifikan, yaitu $76 \%$ dibanding 2 (dua) tahun sebelumnya yang capaian atau realisasinya melebihi target yaitu 2017 sebanyak $112 \%$ dan tahun 2018 sebanyak $116 \%$. Maka dapat dikatakan pemenuhan kewajiban Pajak untuk melaporkan SPT Tahunannya baik Wajib Pajak Orang Pribadi maupun Badan terdampak pada tahun pajak 2019 saat COVID melanda Indonesia.

\section{PEMBAHASAN}

1) Dampak penerimaan pajak baik dari segi kuantitas maupun kualitas saat pendemi COVID-19

Konstribusi pajak pada penerimaan negara sangat mendominasi Anggaran Pendapatan dan Belanja Negara (APBN) setiap tahun fiskal. Tercatat penerimaan pendapatan negara meliputi realisasi 
penerimaan perpajakan sebesar $\operatorname{Rp} 688,94$ triliun dan hal itu telah mencapai 38,57\% dari target pada APBN 2019, dari sisi pertumbuhan, penerimaan perpajakan tumbuh sebesar 5,42\%. Secara lebih rinci, realisasi penerimaan pajak mencapai Rp 603.34 triliun atau 38,25\% dari target APBN 2019, serta mampu tumbuh sebesar $3,75 \%$.

Namun dari catatan Kementerian Keuangan, PPh badan pada bulan Juni 2020 mengalami kontraksi sebesar $38,12 \%$. Perubahan APBN Tahun Anggaran 2020 disebabkan karena terganggunya aktivitas ekonomi. Respon kebijakan fiskal dibutuhkan untuk menghadapi Covid-19, antara lain berupa peningkatan belanja untuk mitigasi risiko kesehatan, melindungi masyarakat dan menjaga aktivitas usaha. Tekanan pada sektor keuangan mempengaruhi APBN Tahun Anggaran 2020 terutama sisi Pembiayaan.

Upaya penyelamatan ekonomi nasional dijalankan melalui beberapa program pemulihan. Untuk itu pemerintah mengeluarkan PP No. 23 Tahun 2020. Perihal Pasal 12 ayat (2) Perppu Stabilitas Sistem Keuangan Penanganan Covid-19, dilaksanakan melalui Perpres No. 54 Tahun 2020. Total tambahan belanja dan pembiayaan APBN 2020 untuk penanganan Covid-19 sebesar Rp405,1 triliun, yang terdiri atas bidang kesehatan dialokasikan Rp75 triliun; Perluasan jaring pengaman sosial Rp110 triliun; Dukungan industri (insentif perpajakan dan stimulus KUR) Rp70,1 triliun; Pembiayaan program pemulihan ekonomi nasional Rp150 triliun. (Syukur, 2020).

Analisa terhadap Penerimaan Pajak dan Pelaporan SPT Tahunan dilakukan untuk melihat dampak Covid-19. Dalam hal ini dengan membandingkan data tersebut dalam 3 tahun terakhir (2017, 2018 dan 2019). Penulis menjadikan data pada KKP Pratama Pontianak sebagai objek yang diteliti terkait dampak Covid-
19 terhadap pemenuhan kewajiban perpajakan. Dan didapatkan diagram batang sebagai berikut:

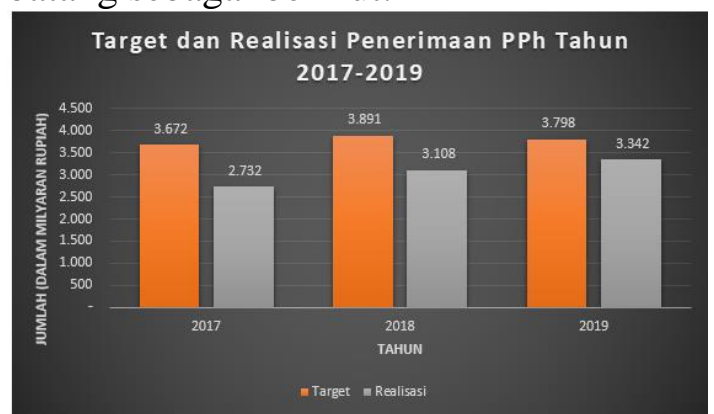

Gambar 4.1 Target dan Realisasi

Penerimaan PPh tahun 2017-2019

Sumber: Data Olahan

Pada gambar 4.1 tidak terlihat trend penurunan untuk penerimaan Pajak Penghasilan ( $\mathrm{PPh}$ ) pada tahun 2019. Dalam hal ini menunjukkan bahwa Covid19 belum berdampak pada pemenuhan kewajiban perpajakan wajib pajak baik badan maupun orang pribadi dalam membayar pajak mereka pada KPP Pratama Pontianak. Angka penerimaan tahun 2019 sebesar 3.342 (dalam Milyaran Rupiah) bahkan meningkat sebesar 234 (dalam Milyaran Rupiah) dari tahun sebelumnya sebesar 3.108 (dalam Milyaran Rupiah). Hal ini juga terjadi pada penerimaan Negara yang berasal dari Pajak Pertambahan Nilai (PPN) dalam diagram batang Gambar 4.2. Dimana pembayaran PPN dari 3.075 (dalam Milyaran Rupiah) menjadi sebesar 3.125 (dalam Milyaran Rupiah), yang artinya meningkat sebesar 50 (dalam Milyaran Rupiah)

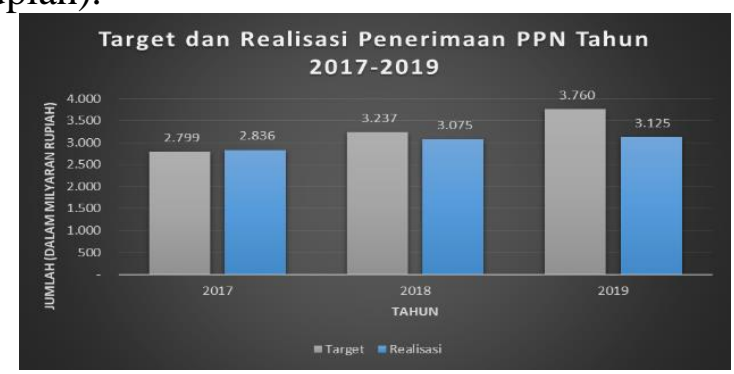

Gambar 4.2 Target dan Realisasi Penerimaan PPN tahun 2017-2019

Sumber: Data Olahan yang Terdaftar pada Kantor Pelayanan Pajak (KPP) Pratama Pontianak Tahun 2020 
Kemudian untuk memperkuat hasil riset peneliti juga melakukan wawancara terhadap perwakilan petugas pajak/fiskus yang diwakili oleh Bapak A T Misbahudin yang merupakan Kasi (Kepala Seksi) Ekstensifikasi dan Penyuluhan di KPP Pratama Pontianak Timur. Hasil wawancara sebagai berikut:

\section{Pertanyaan Pertama:}

Bagaimana Dampak Pendemi COVID-19 yang paling terasa terhadap kinerja institusi atau kantor yang bapak/ibu Pimpin?

\section{Jawaban:}

Dampak pendemi COVID-19 yang paling terasa terhadap kinerja institusi adalah ketika pertengahan Maret dibukanya pojok pajak di beberapa tempat keramaian karena bertepatan dengan bulan terakhir Bayar dan Lapor Pajak dihentikan. Dimana semua kanal-kanal pelayanan yang berhubungan dengan wajib pajak ditutup, maka mengalami keterbatasan dalam menerima assistensi untuk E - Filling, E- Form terkait pengisiannya terutama untuk WP baru.

\section{Pertanyaan Kedua:}

Bagaimana pencapaian target kinerja (realisasi) berkenaan dengan penerimaan pembayaran pajak untuk tahun pajak 2019 oleh wajib pajak (baik wajib pajak orang pribadi maupun badan) yang terdaftar pada KPP Pratama Pontianak karena Pendemi COVID-19 ini?

\section{Jawaban:}

Dampaknya pada baru Pendemi Covid-19 belum terasa terhadap penerimaan, karena penerimaan pembayaran sesuai transaksi dibulan/tahun pajak sebelumnya. Karena pada tahun 2019 usaha WP masih berjalan, dan pembayaran dilakukan dengan E-Billing.
Dimana dari hasil wawancara memperkuat hasil analisa data sekunder bahwa tidak terjadi penurunan pada penerimaan pembayaran pajak atas Pemenuhan Kewajiban Perpajakan oleh Wajib Pajak baik Badan maupun Orang Pribadi yang terdaftar di KPP Pratama Pontianak. Hal ini terkait dengan usaha Wajib Pajak pada tahun pajak 2019 belum terganggu, dan secara pembayaran pajak walaupun dilakukan pada awal tahun 2020 bisa menggunakan fasilitas E-Billing.

Selain melakukan wawancara dengan Petugas Pajak, peneliti juga memberikan beberapa pertanyaan kepada Wajib Pajak (sampel 6 orang) yang ditemui sedang mengantri untuk mendapatkan pelayanan pajak di KPP Pratama Pontianak, dengan data sebagai berikut:

Tabel 4.5 Daftar Responden Wajib

Pajak
\begin{tabular}{|l|l|l|c|}
\hline No & Nawa Wajib Pajak & Jenis Usaha & Lama Usaha \\
\hline 1. & Yunias Trifena Widyayanti & Stockist DRW Skincare & 2 tahun \\
\hline 2. & Ricky Sahbana & Counter Pulsa & 2 tahun \\
\hline 3. & Suci Tri H & Laundry & 4 tahun \\
\hline 4. & M. Yudhi Hardiansyah & Cuci Motor & 5 tahun \\
\hline 5. & Syafril Pink & Pempek Sriwijaya Ompink & 10 tahun \\
\hline 6. & Julairuman Yahya & Percetakan & 10 tahun \\
\hline
\end{tabular}

Sumber: Data Olahan

Hasil wawancara singkat dengan wajib pajak dari tabel 4.5 secara menyeluruh menyampaikan bahwa usaha yang mereka tekuni mengalami penurunan karena pandemic Covid-19. Namun dampak ini dirasakan mulai bulan Maret 2020 hingga saat ini. Sedangkan untuk tahun 2019 masih berjalan normal, maka pembayaran pajak masih berlangsung teratur.

\section{2) Dampak pelaporan pajak baik dari kelengkapan administrasi maupun ketepatan waktu wajib pajak orang pribadi dan badan saat pendemi COVID-19}

Selain pemenuhan kewajiban pembayaran pajak, penulis juga menganalisa terkait kewajiban Lapor SPT Tahunan yang lengkap dan tepat waktu 
dengan membandingkan 3 (tiga) tahun terakhir yang digambarkan dalam diagram batang sebagai berikut:

\section{Gambar 4.3 Target dan Realisasi}

Lapor SPT Tahunan 2017-2019

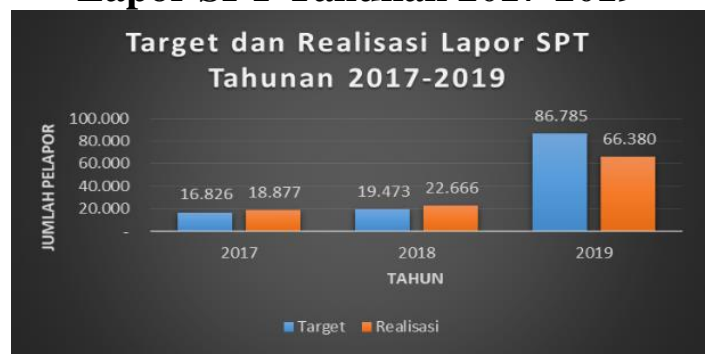

Sumber: Data Olahan

Pada diagram batang 4.3 dapat dilihat terjadi lonjakan nilai target Jumlah pelapor SPT, hal ini terkait dengan peningkatan jumlah Wajib Pajak yang terdaftar pada digram batang 4.4. Namun jika membandingkan angka target dan realisasi digambarkan bahwa pada tahun 2019 tidak mencapai target, sedangkan pada 2 (dua) tahun sebelumnya selalui melampaui target. Pada tahun 2019 target sebesar 86.785 sedangkan realisasi 66.380, hal ini berarti hanya sebesar $76 \%$ efektifitasnya, maka berdasarkan tabel Kriteria Kepatuhan Wajib Pajak range 6080 termasuk dalam "Kurang Patuh". Sedangkan tahun 2017 dan tahun 2018 "Sangat Patuh".

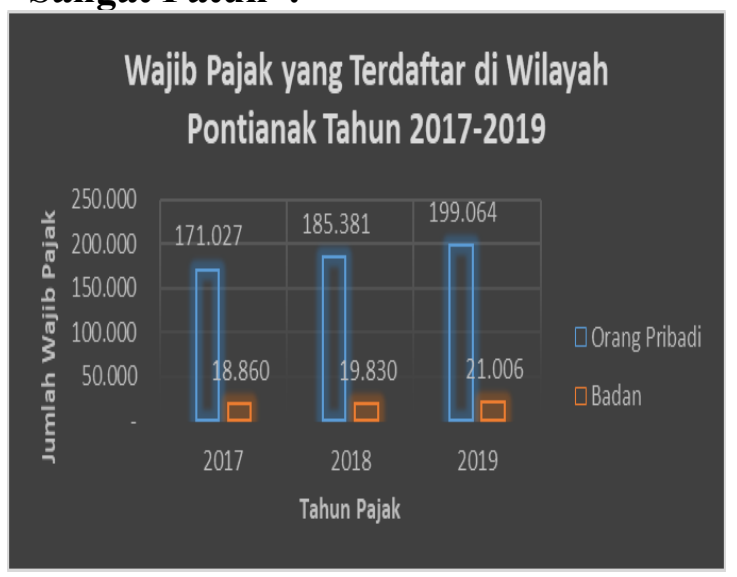

Gambar 4.4 Wajib Pajak yang Terdaftar di Wilayah Pontianak Tahun 2017-2019

Sumber: Data Olahan
Seperti pembahasan sebelumnya terkait pemenuhan kewajiban pembayaran pajak, untuk pemenuhan kewajiban Lapor Pajak juga dilakukan wawancara terhadap fiskus dan wajib pajak. Dengan hasil sebagai berikut:

\section{Pertanyaan ketiga:}

Bagaimana pencapaian target kinerja (realisasi) berkenaan dengan pelaporan pajak untuk tahun pajak 2019 oleh wajib pajak (baik wajib pajak orang pribadi maupun badan) yang terdaftar pada KPP Pratama Pontianak karena Pendemi COVID-19 ini?

\section{Jawaban:}

Pencapaian target pelaporan SPT tahunan agak menurun, karena keterbatasan pelayanan untuk konsultasi dan beberapa kanal-kanal tata pmuka yang berhubungan dengan wajib pajak di tutup/tiadakan. Padahal saat itu sedang boomingnya SPT, dan wajib pajak terutama WP WP baru membutuhkan asistensi untuk aktifkan E-Fin dan pengisian E-Filling maupun E-Form.

Penurunan efektifitas pemenuhan kewajiban perpajakan untuk Pelaporan SPT juga terkomfirmasi oleh wajib pajak. Dimana dari hasil wawancara kepada 6 (enam) wajib pajak didapatkan jawaban bahwa mereka mengalami kesulitan dalam melaporkan pajak untuk tahun pajak 2019, karena pelayanan oleh kantor pajak dibatasi jumlah dan hanya ditemukan di kantor pelayanan pajak yang mengharuskan antri cukup lama. Sedangkan mayoritas mereka masih bingung menggunakan fasilitas E-filling dan E- form.

\section{Pertanyaan Keempat:}

Bagaimana perubahan pelayanan yang dilakukan pada KPP Pratama Pontianak selama masa Pendemi COVID-19 ini? yang Terdaftar pada Kantor Pelayanan Pajak (KPP) Pratama Pontianak Tahun 2020 


\section{Jawaban:}

Pelayanan selama masa Covid 19 mengikuti intruksi pemerintah dengan mematuhi protokoler Covid-19. Dimana dilakukan batasan baik jumlah pelayanan maupun pembatasan internal petugas pemberi layanan. Petugas pajak/fiskus kapasitasnya 50\% dari jumlah sebenarnya, dengan bergantian melakukan WFH (Work From Home). Kemudian sesuai dengan kebijakan Direktorat Jenderal Pajak melakukan relaksasi terkait dengan batas waktu pelayanan lapor pajak SPT Pribadi maupun Badan. Dimana SPT tahunan orang pribadi yang berakhir 31 Maret, diperpanjang sampai dengan 30 April, sedangkan SPT Badan yang berakhir 31 April direlaksasi hingga 30 Juni. Relaksasi tersebut terkait dengan kelengkapannya, maka pada akhir April diperbolehkan melaporkan secara sederhana terlebih dahulu dan dilanjutkan melengkapi berkas lapor pajak hingga akhir Juni. Perpanjangan pelayanan Lapor Pajak ini, diharapkan dapat membantu wajib pajak untuk tetap bisa patuh terhadap kewajiban perpajakan selama kondisi Pendemi Covid -19.

\section{Pertanyaan Kelima:}

Kebijakan seperti apa yang Bapak/Ibu terapkan dalam rangka menjaga/mewujudkan pemenuhan kewajiban perpajakan oleh wajib pajak (baik wajib pajak orang pribadi maupun badan) yang terdaftar pada KPP Pratama Pontianak selama masa Pendemi COVID19 ini?

\section{Jawaban:}

Kebijakan yang diterapkan mengikuti intruksi atau aturan dari pusat atau Direktorat Jenderal Pajak. Sosialisasi dialihkan dengan menggunakan online, yang sebelumnya sering dilakukan dengan tatapmuka. Maka dibuka jadwal kelas online dengan Zoom atau Instagram untuk memenuhi kebutuhan pengetahuan dan informasi memenuhi kewajiban perpajakan. Dan ditambahkan dengan memaksimalkan pelayanan dengan kanalkanal online tambahan melalui WA kantor, Telp kantor, dan Email kantor serta semua AR (Account Representative). Dimana nomor HP AR di publish, dengan harapan tidak hanya tergantung pada nomor kantor, tetapi ada nomor penyanggah, agar wajib pajak tidak merasa kesulitan untuk memenuhi kewajiban pajaknya.

Dari hasil wawancara 2 (dua) pertanyaan terakhir, dapat disimpulkan bahwa KPP Pratama Pontianak Timur sudah memaksimalkan usaha untuk menjaga capaian kinerja terkait pemenuhan kewajiban perpajakan oleh wajib pajak orang pribadi maupun badan yang terdaftar di KPP Pratama Pontianak Timur. Walaupun secara hasil belum dirasa maksimal, maka KPP Pratama Pontianak Timur terus mencoba melakukan beberapa inovasi kearah pelayanan online agak tetap terpenuhi hak wajib pajak untuk mengetahui bagaimana memenuhi kewajiban perpajakan mereka.

\section{SIMPULAN}

1) Hasil penelitian pertama menunjukkan bahwa Covid-19 belum berdampak pada pemenuhan kewajiban perpajakan wajib pajak baik badan maupun orang pribadi yang terdaftar di KPP Pratama Pontianak dalam membayar pajak mereka. Bahkan terjadi peningkatan realisasi penerimaan PPh (Pajak Penghasilan) dari tahun ke tahun, bahkan prosentase capaian juga meningkat, tahun 2017 $74 \%$, tahun 2018 80\% dan tahun 2019 meningkat menjadi $88 \%$. Kemudian realisasi penerimaan PPN (Pajak Pertambahan Nilai) dimana tahun 2017 sebesar Rp 2.836.559.774.006,00 Tahun 2018 sebesar Rp 3.075.539.525.628,00 dan 
meningkat sebesar Rp 50.058.404.887,00 menjadi Rp 3.125.597.930.515,00.

2) Hasil penelitian kedua berdasarkan diagram batang menunjukkan bahwa pemenuhan kewajiban perpajakan oleh wajib pajak yang terdaftar di KPP Pratama Pontianak terkait pelaporan SPT (Surat Pemberitahuan) Pajak Tahunan yang lengkap dan tepat waktu untuk tahun pajak 2019 terjadi lonjakan nilai target Jumlah pelapor SPT sampai dengan sebesar 67.312 wajib pajak. Sedangkan efektifitasnya hanya sebesar $76 \%$ (dengan membandingkan target dan realisasi). Maka pada tahun 2019 masuk kategori "Kurang Patuh". Sedangkan 2 (dua) tahun sebelumnya 2017 dan 2018 pada kategori "Sangat Patuh".

\section{REFERENSI}

Agus, Purwanto. Rudy, Pramono dan Masduki, Asbari. 2020. Studi Eksploratif Dampak Pendemi COVID-19 Terhadap Proses Pembelajaran Online di Sekolah Dasar. E-Jurnal Research Gate. Diakses 20 April 2020 dari, https://www.researchgate.net/publica tion/340661871

Dana, Riksa Buana. 2020. Analisis Perilaku Masyarakat Indonesia dalam Menghadapi Pendemi Virus Corona (COVID-19) dan Kiat Menjaga Kesejahteraan Jiwa. E-Jurnal Research Gate. Diakses 20 April 2020 dari,

https://www.researchgate.net/publica tion/340103659

Direktorat Jenderal Pajak. Peraturan Direktur Jenderal Pajak Nomor PER 08 /PJ /2020, Pub. L. No. PER-08 /PJ 12020 (2020). Indonesia.angga, Indonesia

Estro, Dariatno Sihaloha. 2020. Dampak COVID-19 terhadap Perekonomian
Indonesia. E-Jurnal Research Gate. Diakses 20 April 2020 dari, https://www.researchgate.net/publica tion $/ 340554267$

Guetterman, Timothy C. 2015. Descriptions of Sampling Practices within Fine Approaches to Qualitative Research. E-Jurnal Forum Qualitative Social Research. Vol 16, No. 2. Art. 25 May 2015. Diakses 24 April $2010 \quad$ dari file://D:/Penelitian\%202020/22909645-2-PB.pdf

Iis, Gindarsah. 2020. Dampak PolitikKeamanan COVID-19: Urgensi Komunikasi Risiko. E-Jurnal CSIS Commentaries DMRU-009.

Departemen Politik dan Perubahan SOsial CSIS Indonesia. Diakses 22 April 2020 dari, file:///C:/Users/USER/Downloads/C SIS_Commentaries_DMRU_009_Gi ndarsah\%20(1).pdf

Kusuma, H. 2020. Sri Mulyani Naikkan Batasan Restitusi Hingga Rp 5 Miliar. Detik.Com. Diakses 21 November 2020 dari https://finance.detik.com/beritaekono mi-bisnis/d-4932881/sri-mulyaninaikkan-batasan-restitusi-hinggarp5-miliar\%0AMau

Mardiasmo. 2013. Perpajakan. Edisi revisi. Cetakan Kesembilanbelas. Yogyakarta: Andi.

Menteri Keuangan Republik Indonesia. Peraturan Menteri Keuangan Republik Indonesia Nomor 23/PMK.03/2020, Pub. L. No. PMK 23/PMK.03/2020 (2020). Indonesia.

Menteri Keuangan Republik Indonesia. Peraturan Menteri Keuangan Republik Indonesia Nomor 28/PMK.03/2020, Pub. L. No. PMK 28/PMK.03/2020 (2020). Indonesia.

Menteri Keuangan Republik Indonesia. Peraturan Menteri Keuangan Republik Indonesia Nomor yang Terdaftar pada Kantor Pelayanan Pajak (KPP) Pratama Pontianak Tahun 2020 
44/PMK.03/2020, Pub. L. No. PMK 44/PMK.01/2020 (2020). Indonesia.

Padyanoor, Aswin. 2020. Kebijakan Pajak Indonesia Menanggapi Krisis COVID-19: Manfaat bagi Wajib Pajak. Jurnal Akuntansi. Vol. 30 No.9 Hal 2216-2230. Fakultas Ekonomi dan Bisnis Universitas Airlangga, Indonesia.

Pakpahan, A. K. 2020. Covid-19 Dan Implikasi Bagi Usaha Mikro, Kecil, Dan Menengah. JIHI: Jurnal Ilmu Hubungan Internasional, 20(April), 2-6. Diakses 21 November 2020 dari https://doi.org/https://doi.org/10.265 93/jihi.v0i0.3870.59-64.

Peraturan Pemerintah RI Nomor 1 Tahun 2020 tentang Kebijakan Keuangan Negara dan Stabilitas Sistem Keuangan untuk Penanganan COVID-19 dan/atau Dalam Rangka Menghadapi Ancaman Yang Membahayakan Perekonomian Nasional dan/atau Stabilitas Sistem Keuangan.

Peraturan Menteri Keuangan RI Nomor 23/PMK.03/2020 tentang Insentif Pajak untuk Wajib Pajak Terdampak Wabah Virus Corona.

Peraturan Direktorat Jenderal Pajak Nomor Per-06/PJ/2020 tentang Tatacara Penyampaian, Penerimaan dan Pengolahan Surat Pemberitahuan Pajak Penghasilan Tahun Pajak 2019 Sehubungan dengan Pendemi COVID-19.

Rahayu, Siti Kurnia. 2010. Perpajakan Indonesia Konsep \& Aspek Formal. Graha Ilmu, Yogyakarta.

Resmi, Siti. 2011. Perpajakan, Teori dan Kasus. Buku Satu. Edisi Ketiga. Jakarta : Salemba Empat.

Syukur, Muhammad. 2020. Insentif Pajak terhadap Sumbangan Covid-19 dari Perspektif Relasi Hukum Pajak Indonesia dengan Hak Asasi. Jurnal Suara Hukum Vol 2 Nomor 2.
Magister Ilmu Hukum Ekonomi, Universitas Indonesia,

Wikipedia. 2020. Pendemi COVID 19. Online 